\title{
Angiotensin Converting Enzyme Gene Polymorphism in Egyptian Patients with Systemic Lupus Erythematosus
}

\author{
El-Shafeey M.M., El-Shayeb M., Othman E. and Elfawy N \\ Allergy and Immunology Department of Internal Medicine in Ain Shams University Hospital, \\ Cairo, Egypt.
}

\begin{abstract}
:
Systemic lupus erythematosus (SLE) shows various clinical manifestations with various immunological abnormalities. The development of lupus nephritis and vasculitis is common in patients with SLE. As angiotensin I-converting enzyme (ACE) has been reported to be associated with various immunological phenomena, we investigated the correlation between insertion(I) / deletion(D) polymorphism of the ACE gene and SLE. Fifty Egyptian patients with SLE and thirty healthy control persons were involved in this study. ACE gene was detected by the polymerase chain reaction (PCR).

In SLE patients, there is a significant difference when comparing DD and II genotypes $(\mathrm{P}<0.05)$, being higher in the DD genotype. And a highly significant difference when comparing ID and II genotypes $(\mathrm{P}=0.001)$, being much higher in ID genotype than II genotype. According to vasculitis, there is a significant relationship between vasculitis and patients genotypes when comparing ID genotype with both II and DD genotypes $(\mathrm{P}<0.05)$, being highest in ID genotype. There is a significant relationship found when comparing ID genotype with both II and DD genotypes, being highest in ID genotype in patients with score $\geq 21$. These results suggest that the ACE genotype could be associated with SLE.
\end{abstract}

\section{Introduction:}

SLE is an autoimmune disorder of unknown etiology, which is known to occur in genetically susceptible patients influenced by environmental and hormonal factors (Uhm et al., 2002). SLE has a strong genetic component: $4 \%$ of cases are familial (Blakemore et al., 1994), increased concordance of SLE among monozygotic versus dizygotic twins (Fronek et al., 1990), abnormal $\mathrm{T}$ cell suppressor function in healthy relatives of SLE patients with increased antibody production (Fronek et al., 1990), antinuclear and other autoan-tibodies (Hahn, 1998) and increased prevalence of other connective tissue diseases, compared with relatives of matched controls (Blakemore et al., 1994), and associations with several major histocompatibility complex (MHC) loci (Fronek et al., 1990).

The development of lupus nephritis is not only common, but is associated with significant morbidity and mortality (Cervera et al., 1999). Both SLE and endstage renal disease (ESRD) show clear familial patterns, suggesting genetic component to disease development and/or progression (Schelling et al., 1999).

Although contemporary immunosuppressive treatments may counteract immune mechanisms involved in the pathogenesis of nephritis, an increasing fraction of glomeruli, especially those that have undergone adaptive hypertrophy, may continue to undergo progressive sclerosis even after nephritis has become quiescent (Tassiulas et al., 1998). This suggests that in addition to immune mechanisms, nonimmune pathogenic mecha-nisms such as glomerular hyperperfusion, intra-glomerular and systemic hypertension, and proteinuria may play a role in the progression of the renal disease (Davis et al., 1996). Thus, in addition to genes that may be implicated in the dysregulation of immune mechanisms in SLE, such as Fc $\gamma$, other genes may also influence the severity and response to treatment of lupus nephritis (Kono \& Theofilopoulos, 1996). Tassiulas et al. (1998), hypothesized that genes of the RAS may be among such candidate genes. 
Vasculopathy is a common manifestation in SLE that occurs in about $50 \%$ of SLE patients, either in the form of mucocutaneous vasculitis, a vasculitis associated with visceral organ impairment, thrombotic events, or Raynaud's phenomenon (Uhm et al., 2002). Involvement of the renal vasculature is not uncommon in lupus nephritis and its presence can adversely affect the prognosis of the renal disease. Since Raynaud's phenomenon originates from vascular and microvascular lesions, endothelial cell injury or dysfunction has been proposed as a pathogenic mechanism. Evidence of endothelial cell dysfunction in Raynaud's phenomenon includes changes in prostacyclins, thromboxanes, and ACE (Uhm et al., 2002).

Disease activity can be defined as the reversible manifestations of the underlying inflammatory process. It is a reflection of the type and severity of organ involvement at each point in time (Bombardier et al., 1992). The weights assigned to each variable do not always correspond to the degree of inflammation present, instead they may relate to the seriousness of the organ involvement according to the life threatening nature or threat to the functional capacity of the individual. Patients with clinically active lupus typically have increased levels of anti-DNA antibodies, depressed complement levels and a significant raised titer of antinuclear antibodies. Moreover, resolution in these abnormalities has shown to correlate with improvement in the clinical course of lupus nephritis (Laitman et al., 1989). Based on these observations immunological studies are often used as early pre-clinical markers of changing lupus activity (Gladman \& Urowitz, 1995).

ACE activates angiotensin I into angiotensin II, inactivates bradykinin via the kallikrein-kininogen system, and plays a major role in rennin-angiotensin system (RAS) (Gladman \& Urowitz, 1995).

The RAS is an important regulator of arterial blood pressure, at both systemic and tissue levels (Egido, 1996). Recently, there is increasing evidence to suggest that activation of the intrarenal RAS might play a key role in controlling the progression of renal scarring (Liu et al., 2003).

Angiotensin II, the main effector molecule of the RAS, is a vasoactive peptide and growth factor that contributes to vascular reactivity, tissue remodeling and fibrosis (Klahr \& Morrissey, 2000). It is also a potent proinflammatory modulator with the ability to augment and perpetuate immune responses in renal and non-renal tissues (Suzuki et al., 2000).

Angiotensin II is a pleiotropic molecule and strong candidate as a mediator of the development and progression of renal disease in SLE (Parsa A et al.,2002). It can increase the synthesis of extracellular matrix, (Mezzano et al.,2001) and induces mesangial cell proliferation with subsequent hypertrophy and cell differe-ntiation. Mesangial cells can produce inflammatory mediators such as oxygen free radicals and endothelin and can initiate inflammatory responses in the glomerulus (Eliahou et al., 2001).

Inhibition of angiotensin II in experimental and human renal diseases decreases proteinuria, improves systemic and intraglomerular hypertension, reduces histologic evidence of renal injury and slows progression to ESRF (Tassiulas et al., 1998).

ACE also forms part of the sophisticated regulatory system of vascular tone. Modification of the local hormone equilibrium might result in increased neointimal proliferation, increased cellular matrix formation and monocyte adhesion, as well as cell activation with the subsequent release of growth factors and proinflammatory cytokines, platelet aggregation, processes of homeostasis and chronic/acute vasospasm(Pullmann et al., 1999).

ACE gene is located on the long arm of chromosome 17 and shows characteristic insertion/deletion (I/D) polymorphism based on the presence or absence of a 287 bp long Alu repeat sequence within intron 16 which results in three possible genotypes: DD, II, ID (Uhm et al., 2002).

I/D polymorphism in intron 16 of the ACE gene is responsible for $\sim 40 \%$ of the variability of serum and cellular (tissue) concentration of ACE levels among 
different individuals (Tassiulas et al., 1998). Carriers of the DD genotype have the highest levels of serum ACE and those of the II genotype the lowest serum levels, being about 2 fold higher ACE levels in DD genotype than II one (Köppel et al., 2004). This is reportedly associated with several cardiovascular or renal disorders (Sato et al., 1998). In addition, several studies have reported an association of DD genotype with adverse vascular events such as renal artery disease (Missouris et al., 1996), carotid artery disease (Kauma et al.,1996), strokes (Catto et al., 1996) and coronary artery spasm (Oike et al., 1995) contributing to early mortality. In addition to its hemodynamic effects, ACE affects various immunological phenomena through angiotensin II, kinins or neuropeptides. Since immunological abnormalities appear to be directly related to the disease process of SLE, it is reasonable to predict that ACE gene polymorphism would contribute to the activity of SLE through affecting the systemic and local concentrations of ACE (Sato et al., 1998).

In this study, investigations were done to correlate the relation between I/D polymorphism of ACE gene and the clinical manifestations of SLE, especially vascular involvement and lupus nephritis.

This work was carried out at the Medical Research Center (MRC), Faculty of medicine, Ain Shams University.

\section{Subjects \& method}

The study group consisted of 80 persons attending the department of medicine in Ain Shams University Hospitals. The subjects studied were classified to:30 healthy volunteers, their ages ranged between 35-58 with a mean age 43 years $\& 50$ patients, their ages ranged between 1144 with a mean age 28 years. Each patient met more than four of the revised criteria for the diagnosis of SLE proposed by the American Rheumatism Association (ARA) (Tan et al., 1982).

Samples for the PCR were immediately stored at -70 . The DNA was extracted from the samples (whole blood); each sample was subjected to a consensus primer mediated PCR method, which is able to amplify a 190 base pair (bp) fragment in the absence of insertion and $490 \mathrm{bp}$ in the presence of insertion in the ACE gene.

A third fragment with an intermediate molecular weight is present in PCR from heterozygotes, and corresponds to a heteroduplex DNA fragme. The standard PCRs were carried out in $50 \mu \mathrm{l}$. A oneminute initial denaturation step at $94^{\circ}$ was followed by 35 cycles of amplification with a PCR processor. Each cycle included a denaturation, annealing and extension step. The reaction mixture was analyzed by electrophoresis on $2 \%$ agarose in tris acetate EDTA buffer, stained with ethidium bromide to be visualized under ultra violet transilluminat Marker gave different bands ranging between 100-2000 bp, the 190-490 bp fragment was located.

The samples were examined for the presence of sharp band at 490 bp that means II, at $190 \mathrm{bp}$ equal DD, and 190-490 denotes ID.

\section{Results}

The control subjects versus SLE patients regarding their ACE genotypes is shown in table number 1 , there is no significant difference found between the patients \& the control subjects $(\mathrm{P}>0.05)$. Yet in SLE patients, there is a significant difference when comparing DD and II genotypes $(\mathrm{P}<0.05)$, being higher in the DD genotype. And a highly significant difference when comparing ID and II genotypes $(\mathrm{P}=0.001)$, being much higher in ID genotype than II genotype. There is no significant difference when comparing DD and ID genotypes $(\mathrm{P}>0.05)$ in SLE patients. According to control subjects, there is no significant difference found between them $\&$ their genotypes.

Frequencies of different ACE genotypes in SLE patients with nephritis is shown in table number 2. Although there is an obvious increase in the frequency of ID genotypes, there is no significant relationship found when comparing all the three genotypes with each other $(\mathrm{P}>0.05)$. Frequencies of different ACE genotypes in SLE patients with vasculitis is shown in 
table number 3, there is a significant relationship between vasculitis and patients genotypes when comparing ID genotype with both II and DD genotypes $(\mathrm{P}<0.05)$, being highest in ID genotype. Yet there is no significant relationship when comparing DD and II genotypes ( $\mathrm{P}>0.05)$.

SLE Disease Activity Index (SLEDAI) score in comparison to genotypes of patients is shown in table number 4 , there is no significance found when comparing II genotype with DD genotype. Yet, there is a significant relationship found when comparing ID genotype with both II and DD genotypes, being highest in ID genotype in patients with score $\geq 21$.

Fig. (1): Polaroid photographs of the DNA bases of the ACE gene. A. All samples show sharp bands at 190 and 490 bp that denotes ID polymorphism. B. Samples 1 and 5 show sharp bands at only 190 bp denoting DD polymorphism.

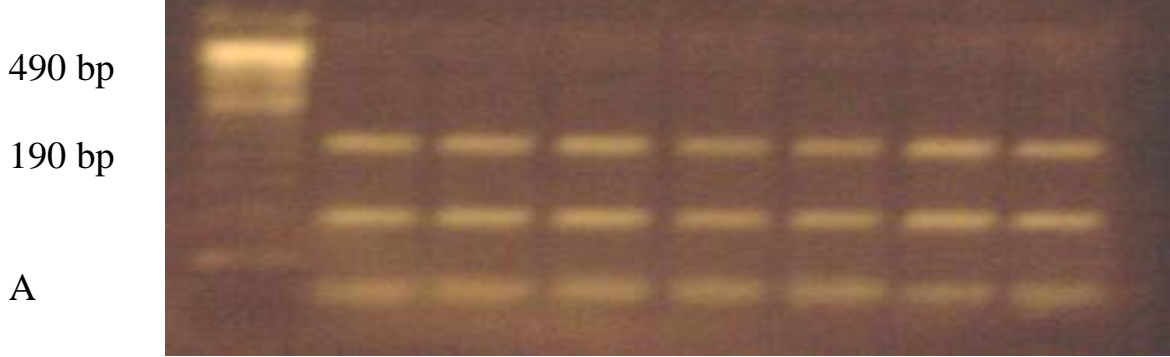

490 bp

$190 \mathrm{bp}$

B

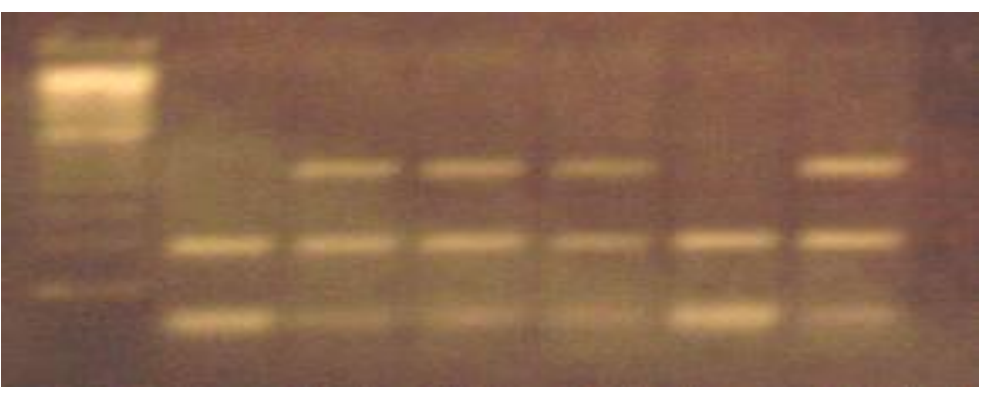

Table (1): The control subjects versus SLE patients regarding their ACE genotypes

\begin{tabular}{|l|l|l|l|}
\hline & DD & ID & II \\
\hline Patients (No.50) & $18(36 \%)$ & $27(54 \%)$ & $5(10 \%)$ \\
\hline Control (No.30) & $11(35 \%)$ & $12(40 \%)$ & $7(25 \%)$ \\
\hline
\end{tabular}

Table (2): Frequencies of different ACE genotypes in SLE patients with nephritis

\begin{tabular}{|l|l|l|l|}
\hline & DD & ID & II \\
\hline Nephritis (No.18) & $6(33.3 \%)$ & $11(61.1 \%)$ & $1(5.6 \%)$ \\
\hline
\end{tabular}

Table (3): Frequencies of different ACE genotypes in SLE patients with vasculitis

\begin{tabular}{|l|l|l|l|}
\hline & DD & ID & II \\
\hline Vasculitis (No.10) & $2(20 \%)$ & $8(80 \%)$ & 0 \\
\hline
\end{tabular}

Table (4): SLE Disease Activity Index (SLEDAI) score in comparison to genotypes of Patients

\begin{tabular}{|c|c|c|c|}
\hline & DD & ID & II \\
\hline SLEDAI score 0-10 (No. 28) & $12(42.9 \%)$ & $12(42.9 \%)$ & $4(14.3 \%)$ \\
\hline SLEDAI score 11-20 (No. 11) & $3(27.3 \%)$ & $7(63.6 \%)$ & $1(9.1 \%)$ \\
\hline SLEDAI score $\geq 21($ No.11) & $3(27.3 \%)$ & $8(72.7 \%)$ & 0 \\
\hline
\end{tabular}




\section{Discussion}

The precise etiology of SLE remains unknown, but many studies have revealed that genetic and environmental factors are implicated in the development of SLE. However, the genetic basis for the susceptibility to the disease or for the activity of the disease has yet to be fully explained. The immunological abnormalities are considered to be responsible for the pathogenesis of SLE. As angiotensin I converting enzyme (ACE) has been reported to be associated with various immunological phenomena, we investigated the correlation between I/D polymorphism of the ACE gene and the disease activity of SLE (Sato et al., 1998).

In the present work, there was no correlation found between different ACE genotypes in Egyptian SLE patients versus control subjects. This is in agreement with Sato et al. (1998), Uhm et al. (2002) \& Kaufman et al. (2001) on AmericanEuropean subjects. In contrast, Tassiulas et al. (1998) found a lower frequency of DD genotype \& the D allele in AfricanAmerican SLE patients as compared to African-American normal controls. Kaufman et al. (2001) showed that the DD genotype was much more common in the SLE affected African-American than unaffected subjects.

Among normal subjects, the present work found no significant relationship when comparing their different genotypes. Tassiulas et al. (1998) reported that African American normal subjects had a higher prevalence of DD genotype as compared to Caucasian normal controls.

Among SLE Egyptian patients, the present work reported a significant increase in the DD genotypes when compared with the II genotype and a highly significant increase in the ID genotype when compared to the II genotype. Parsa et al. (2002) reported the same findings as regard nonCaucasian subjects. They reported a possible protective effect of the I haplotype.

It is proved that there is no significant differences between SLE patients with and without nephritis as regard their ACE genotypes. This is in agreement with Akai et al. (1999), Uhm et al. (2002) \& Molad et al.(2000) on Israeli lupus patients. However, Tassiulas et al. (1998) reported a trend of increased frequency of $\mathrm{I}$ and decreased frequency of D as likelihood of renal disease increases. In contrast, Kaufman et al. (2001) reported higher frequency of the DD allele in SLE patients with renal involvement as compared to unaffected family members. Parsa et al. (2002) found that the Alu D haplotype was preferentially transmitted among the nonCaucasian lupus nephritis group. In a study of Chinese lupus patients, the ACE DD genotype was associated with lupus nephritis, but the ID genotype was associated with severity and the poor prognosis in patients with lupus nephritis (Guan et al., 1997).

According to lupus vasculitis in this work, its diagnosis based on presence of tender finger nodules, periungual infarction, ulceration, gangrene or splinter hemorrhage. Moreover, presence of cerebrovascular accidents, seizures or psychosis in absence of metabolic or drug causes indicates cerebral vasculitis and was proved by the CT or MRI brain. The present work reported a significant increase in the ID genotype in relation to the II and the DD genotypes in patients with lupus vasculitis.

Uhm et al. (2002) based on presence of Raynaud's phenomenon, hypertension, livedo reticularis and antineutrophil cytoplasmic antibody to diagnose lupus vasculitis, they found a significant skewing in the ACE genotypes in relation to Raynaud's phenomenon, being related to the ID genotype However, they reported no association with the other parameters related to vasculopathy.

Regarding lupus activity, the present work depends on the SLEDAI score to evaluate it. The results showed that the patients with ID genotypes had significantly higher SLEDAI score. This is in agreement with Sato et al. (1998) who reported that patients with II or ID had significantly higher SLEDAI score than those with DD genotype. However, Molad et al (2000) found no relation between SLEDAI score 
and different ACE genotypes. Tassiulas et al. (1998) depended on renal biopsy to evaluate the activity and chronicity index and found no relation with the three genotypes of ACE genotypes.

\section{Conclusion}

Results of this study showed that ACE genotype frequencies are similar among SLE patients and controls; however, regarding the patients' genotypes, the II polymorphism is significantly low being as a protective genotype against SLE development.

Although this study succeeded to find a relation between ACE genotypes and lupus vasculitis, it failed to establish such a relation with lupus nephritis. In patients with vasculitis, ACE gene II genotype was found significantly lower than other genotypes, acting again as a protective genotype against the development of vasculitis in SLE patients.

Lupus activity was assessed in this study using SLEDAI score. Results showed that the ID polymorphism was significantly higher than both DD and II polymorphisms in patients with high SLEDAI score.

Therefore, the results of the present work suggest that ACE gene polymorphism may be associated with the development and activity of systemic lupus erythematosus. This specific polymorphism may have a prognostic value in evaluating SLE patients. Further study with greater number of patients should be performed to clarify the implication of this polymorphism for SLE patients.

\section{References}

1. Akai Y, Sato H, Iwano M, Kurumatani N, Kurioka H, Kubo A, Yamaguchi T, Shiiki H, Fujimoto T and Dohi K, 1999: Asso-ciation of an insertion polymorphism of angiotensin-converting enzyme gene with the activity of lupus nephritis. Clinical Nephrology, 51(3); 141-146.

2. Blakemore AIF, Tarlow JK, Cork MJ, Gordon C, Emery P and Duff GW, 1994: Interleukin-1 receptor antagonist gene polymorphism as a disease severity factor in systemic lupus erythematosus. Arthritis Rheum, 37(9); 1380-1385.

3. Bombardier C, Gladman DD, Urowitz $\mathrm{MB}$, Caron $\mathrm{D}$, Chang $\mathrm{CH}$ and the Committee on Prognosis Studies in SLE, 1992: Derivation of the SLEDAI: a disease activity index for lupus patients. Arthritis Rheum, 35(6); 630-640.

4. Catto A, Carter AM, Barrett JH, Stickland M, Bamford J, Davies JA and Grant PJ, 1996: Angiotensin-converting enzyme insert-ion/deletion polymorphism and cerebrova-scular disease. Stroke, 27(3); 435-440.

5. Cervera R, Khamashta MA, Font J, Sebastiani GD, Gil A, Lavilla P, Aydintug AO, Jedryka-Goral A, de Roman E, Fernandez-Nebro A, Galeazzi M, Haga HJ, Mathieu A, Houssiau F, Ruiz-Irastorza G, Ingelmo $M$ and Hughes GR, 1999: Morbidity and mortality in systemic lupus erythematosus during a 5year period. A multicenter prospective study of 1,000 patients. European Working Party on Systemic Lupus Erythematosus. Medicine (Baltimore), 78(3); 167-175

6. Davis JD, Tassiulas IO and Boumpas DT, 1996: Lupus nephritis. Curr Opin Rheumatol, 8; 415-423.

7. Egido J, 1996: Vasoactive hormones and renal sclerosis. Kidney Int, 49; 578-597.

8. Eliahou H, Avinoach I, Shahmurov M, Ben-David A, Shahar C, Matas $Z$ and Zimlichman R, 2001: Renoprotective effect of angiotensin II receptor antagonists in experimental chronic renal failure. AM J Nephrol, 21; 78-83

9. Fronek Z, Timmerman LA, Alper CA, Hahn BH, Kalunian K, Peterlin BM and McDevitt HO, 1990: Major histocompatibility complex genes and susceptibility to systemic lupus erythematosus. Arthritis Rheum, 33(10); 1542-1553.

10. Gladman DD and Urowitz MB, 1995: Clinical of SLE, edited by John $\mathrm{H}$. Kilippel-paul A Dieppe; 305-316.

11. Guan T, Liu $Z$ and Chen Z, 1997: Angiotensin-converting enzyme gene polymorphism and the clinical pathological features and progression in lupus nephritis. Zhonghua Nei Ke Za Zhi, 36(7); 461-464.

12. Hahn BH, 1998: Antibodies to DNA. N Engl J Med, 338; 1359-1368.

13. Kaufman KM, Kelly J, Gray-Mcguire C, Asundi N, YU H, Reid J, Baird T, Hutchings D, Bruner G, Scofield RH, Moser K and Harley JB, 2001: Linkage 
analysis of angiotensin-converting enzyme (ACE) insertion/deletion polymorphism and systemic lupus erythematosus. Molec Cell Endocrinol, 177; 81-85.

14. Kauma HP, Paivansalo M, Savolainen MJ, Rantala AO, Kiema TR, Lilja M, Reunanen A and Kesaniemi YA, 1996: Association between angiotensin converting enzyme gene polymorphism and carotid atherosclerosis. J Hypertens, 14; 1183-1187.

15. Klahr S and Morrissey JJ, 2000: The role of vasoactive compounds, growth factors and cytokines in the progression of renal disease. Kidney Int, 57 (suppl 75); S7-S14.

16. Kono DH and Theofilopoulos AN, 1996: Genetic contributions to systemic lupus erythematosus. J Autoimmun, 9; 437-452.

17. Köppel H, Renner W, Gugl A, Cichocki L, Gasser R, Wascher TC and Pilger E, 2004: The angiotensin-converting-enzyme insertion/ deletion polymorphism is not related to venous thrombosis. Thromb Haemost, 91; 76-79.

18. Laitman RS, Glicklich D and Sablay LB, 1989: Effect of long term normalization of serum complement levels on the course of lupus nephritis. Am J Med, 87; 132-138.

19. Liu BC, Sun J, Chen Q, Ma KL, Ruan XZ and Phillips AO, 2003: Role of connective tissue growth factor in mediating hypertrophy of human proximal tubular cells induced by angiotensin II. Am J Nephrol, 23; 429-437.

20. Mezzano SA, Ruiz-Ortega and Egido J, 2001: Angiotensin II and renal fibrosis. Hypertension, 38; 635-638.

21. Missouris CG, Barley J, Jeffery S, Carter ND, Singer DR and MacGregor GA, 1996: Genetic risk for renal artery stenosis: association with deletion polymorphism in angiotensin I-converting enzyme gene. Kidney Int, 49(2); 534-537.

22. Molad Y, Gal E, Magal N, Sulkes J, Mukamel M, Weinberger A, Lalazari S and Shohat M, 2000: Renal outcome and vascular morbidity in systemic lupus erythe-matosus (SLE): lack of association with the angiotensin-converting enzyme gene polymo-rphism. Semin Arthritis Rheum, 30; 132-137

23. Oike Y, Hata A, Ogata Y, Numata Y, Shido K and Kondo K, 1995: Angiotensin converting enzyme as a genetic risk factor for coronary artery spasm. Implication in the pathogenesis of myocardial infarction. J Clin Invest, 96(6); 2975-2979.

24. Parsa A, Peden E, Lum RF, Seligman VA, Olsen JL, Li H, Seldin MF and Criswell LA, 2002: Association of angiotensin-converting enzyme polymorphisms with systemic lupus erythematosus and nephritis: analysis of 644 SLE families. Genes and Immunity, 3(suppl 1); S42-S46.

25. Pullmann R Jr, Lukac J, Skerenova M, Rovensky J, Hybenova J, Melus V, Celec S, Pullmann $R$ and Hyrdel R, 1999: Association between systemic lupus erythematosus and insertion/deletion polym-orphism of the angiotensin-converting enzyme (ACE) gene. Clin Exp Rheumatol, 17; 593596

26. Sato H, Akai Y, Iwano M, Kurumatani N, Kurioka H, Kubo A, Yamaguchi T, Fujimoto $T$ and Dohi $K$, 1998: Association of an insertion polymorphism of angiotensin-converting enzyme gene with the activity of systemic lupus erythematosus. Lupus, 7; 530-534.

27. Schelling JR, Zarif L, Sehgal A, Iyengar $S$ and Sedor JR, 1999: Genetic susceptibility to end-stage renal disease. Curr Opin Nephrol Hypertens, 8; 465-472.

28. Suzuki Y, Ruiz-Ortega $M$ and Egido J, 2000: Angiotensin II: a double-edged sword in inflammation. J Nephrol, 13 (suppl 3); S101-S110.

29. Tan EM, Cohen AS, Fries JF, Masi AT, McShane DJ, Rothfield NF, Schaller JG, Talal $N$ and Winchester RJ, 1982: The 1982 revised criteria for the classification of systemic lupus erythematosus. Arthritis Rheum, 25(11); 1271-1277.

30. Tassiulas IO, Aksentijevich I, Salmon JE, Kim Y, Yarboro CH, Vaughan EM, Davis JC, Scott DL, Austin HA, Klippel JH, Balow JE, Gourley MF and Boumpas DT, 1998: Angiotensin I converting enzyme gene polymorphisms in systemic lupus erythematosus: decreased prevalence of DD genotype in African American patients. Clinical Nephrology, 50(1); 8-13.

31. Uhm WS, Lee HS, Chung YH, Kim TH, Bae SC, Joo KB, Kim TY and Yoo DH, 2002: Angiotensin-converting enzyme gene polymorphism and vascular manifestations in Korean patients with SLE. Lupus, 11; 227-233 


\section{تعدد شكل جين ألانزيم المحول للأنجيوتينسين فى المرضى المصرين

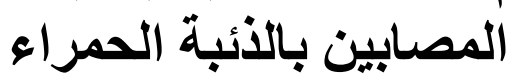

محمد مدحت الثافعى ، محمد عبد الرحمن الثائب ، ايمان نجيب عثمان ،

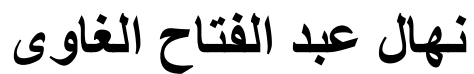

وحدة المناعة و الحساسية ـ قسم الباطنة ــ مستشفى عين شمس الجامعى

يظهر مرض الذئبة الحمر اء باثنكال اكلينيكية مختلفة و بتغير ات مناعية مختلفة.

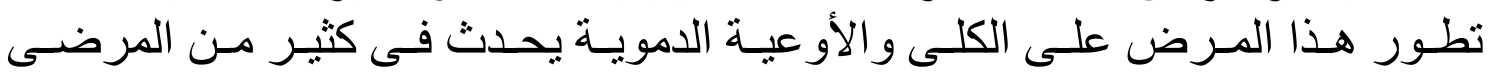

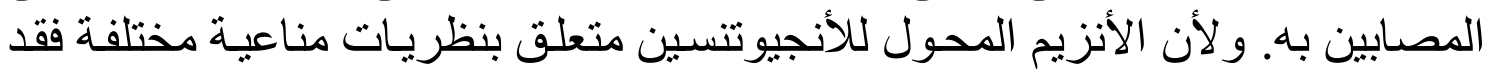

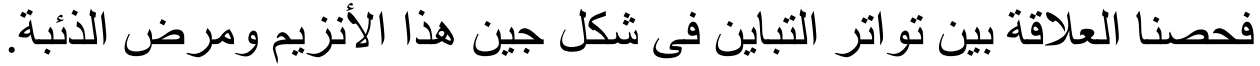

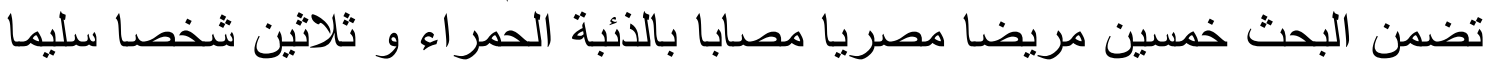

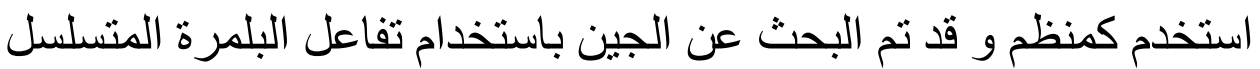

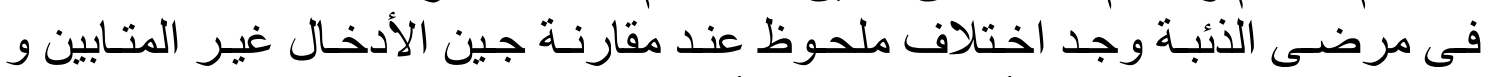
الحذف غير المتابين بكونه أكثر فى جين الأدخال غير المتابين و اختلاف ملحوظ الإندا

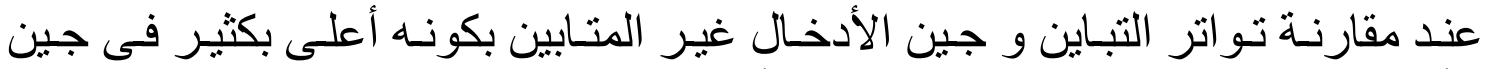

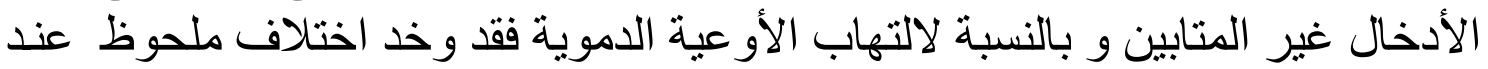

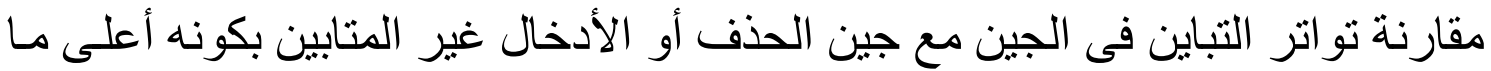

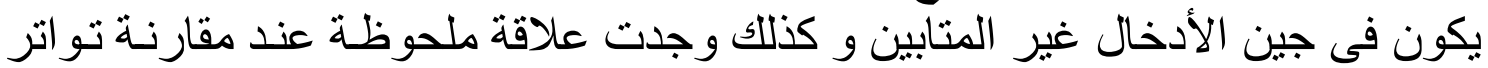

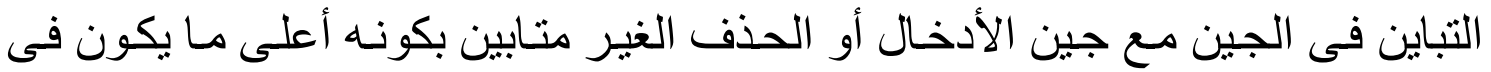

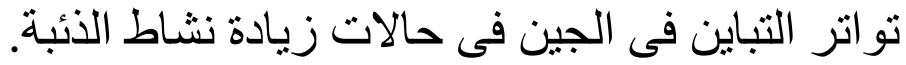
هذه النتائج تحتمل وجود التين فلاقة بين المرض زئن وجين الأنزيم المحول للأنجيو تنسين. 